\title{
NORTHERN PYGMY-OWL PREDATION ON AN ADULT CALIFORNIA QUAIL
}

\author{
MITCHEL D. BOSMA, HAYLEY H. ROSS, and ROBERT B. DOUGLAS, \\ Mendocino Redwood Company, P.O. Box 489/32601 Holquist Lane, Fort Bragg, \\ California 95437; rdouglas@humboldt.edu (current address of Bosma, P.O. Box \\ 371, Boonville, California 95415; of Douglas, Strix Wildlife Consulting, 32850 \\ Collins Lane, Fort Bragg, California 95437)
}

The Northern Pygmy-Owl (Glaucidium gnoma) opportunistically hunts and feeds on songbirds, small mammals, reptiles, and insects (Merrill 1888, Holman 1926, Brock 1958, Bull et al. 1987). Diet studies indicate that although pygmy-owls feed primarily on species smaller than themselves, they also take species with body masses similar to or slightly larger than themselves (70-100 g; Giese and Forsman 2003). Occasionally they take even larger prey (i.e. $\geq$ twice body mass, such as the Northern Flicker (Colaptes auratus; Holt and Leroux 1996).

Few direct observations of predation of relatively large species have been reported in the literature: Northern Pygmy-Owls have been observed preying on species of the family Odontophoridae, including the Northern Bobwhite (Colinus virginanus; Aiken and Warren 1914), Gambel's Quail (Callipepla gambelii; Kimball 1925), and an immature female California Quail (Callipepla californica; Balgooyen 1969). Other accounts have reported pygmy-owls preying on and attacking immature domestic chickens (Gallus gallus domesticus), specifically "chick[s]" (Walker 1924:181) and "half grown chickens" (Aiken and Warren 1914:513). Holt and Norton (1986) also

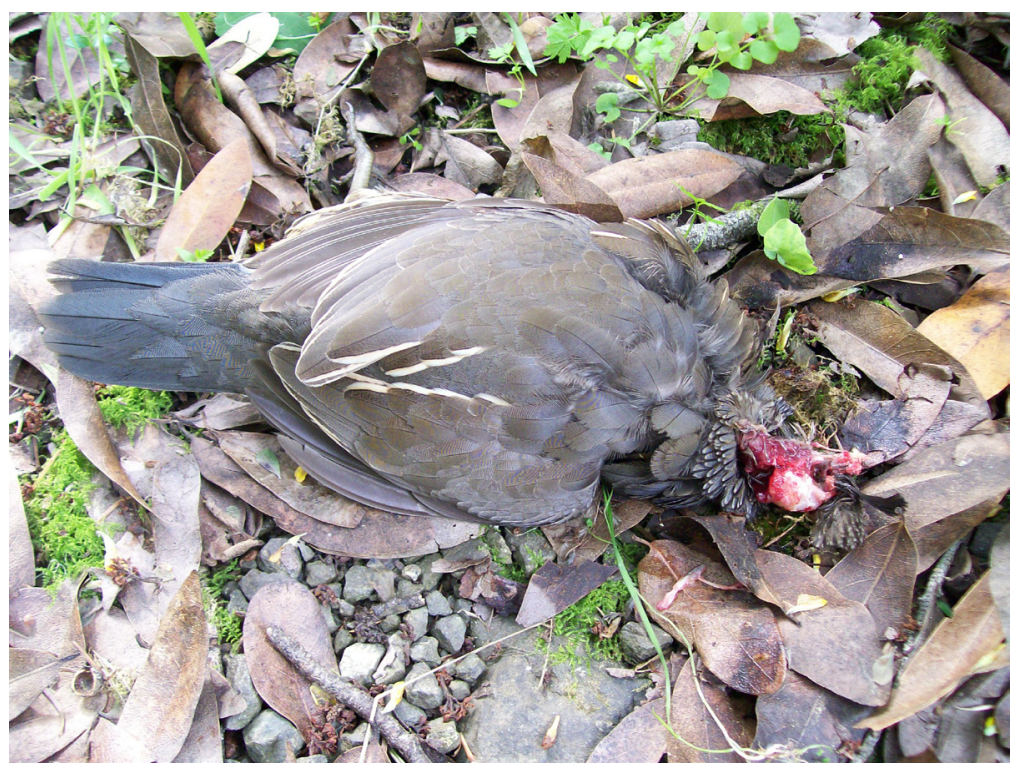

FIGURE 1. California Quail killed and partially eaten by a Northern Pygmy-Owl near Elk, Mendocino County, California, 13 April 2007.

Photo by Mitchel D. Bosma 
observed a female Northern Pygmy-Owl kill and feed on a Red Squirrel (Tamiasciurus hudsonicus), possibly representing the largest mammalian species confirmed as prey. However, diet studies typically identify prey from sparse remains found in pellets and around nests, and most historical observations of predation lack specific information such as mass, condition, or developmental stage from which the size of the prey can be gauged. An exception is Balgooyen (1969), who provided a photograph and mass measurements of both the California Quail and Northern PygmyOwl. We add to this body of observations by providing an account of a Northern Pygmy-Owl feeding on an adult male California Quail.

On 13 April 2007 at 16:48, after visiting a known Northern Spotted Owl (Strix occidentalis caurina) territory located $2.4 \mathrm{~km}$ east of Elk, Mendocino County, California $\left(39.0759^{\circ} \mathrm{N}, 123.4213^{\circ} \mathrm{W}\right)$, Bosma observed a Northern Pygmy-Owl fly up from the side of a seasonal road and perch in a Red Alder (Alnus rubra), where it remained fixated on its previous location. Bosma lured the bird closer with a live mouse placed atop a Douglas-Fir (Pseudotsuga menziesii) sapling. After several minutes of intently watching the mouse, the owl captured the mouse and flew to the ground with it out of view. Bosma then investigated the spot where the owl had been initially seen and discovered a dead adult male California Quail. The carcass was still warm and flexible, indicating it was recently killed. The quail was mostly clean and undamaged, with nearly all its body and flight feathers intact, but its head had been stripped of flesh and eaten down to the skull. From the condition of the quail carcass and the manner in which it was killed, we inferred that the pygmy-owl killed the quail.

Although we did not weigh the quail carcass, the reported mean mass for the subspecies of the California Quail (C.c. brunnescens) in coastal northern California is $180+\mathrm{g}$ for both sexes (Sumner 1935). The body mass of quail fluctuates seasonally with males attaining peak body mass in early spring (Genelly 1955, Lewin 1963). In comparison, the Northern Pygmy-Owl has an average mass of $64.5 \mathrm{~g}$ (range, both sexes: $45-75 \mathrm{~g}$, standard deviation $=7.2, n=50$, Bird Banding Laboratory data 2013-2018).

Accounts of pygmy-owls killing large prey, though few, span over a century. Further studies on the Northern Pygmy-Owl's feeding behavior are necessary to understand if specific demographic and/or ecological factors drive the occasional selection of large prey or if this behavior is more associated with chance opportunity.

\section{LITERATURE CITED}

Aiken, C. E. H., and Warren, E. R. 1914. The birds of El Paso County, Colorado. Colo. College Sci. Ser. 12:455-603; doi 10.5962/bhl.title.54105.

Balgooyen, T. G. 1969. Pygmy Owl attacks California Quail. Auk 86:358; doi $10.2307 / 4083519$.

Brock, E. M. 1958. Some prey of the Pygmy Owl. Condor 60:338.

Bull, E. L., Hohmann, J. E., and Henjum, M. G. 1987. Northern Pygmy-Owl nests in northeastern Oregon. J. Raptor Res. 21:77-78.

Genelly, R. E. 1955. Annual cycle in a population of California Quail. Condor 57:263-285; doi 10.2307/1364732.

Giese, A. R., and Forsman, E. D. 2003. Breeding season habitat use and ecology of male Northern Pygmy-Owls. J. Raptor Res. 37:117-124.

Holman, F. C. 1926. Nesting of the California Pygmy Owl in Yosemite. Condor 28:92-93; doi 10.2307/1362930.

Holt, D. W., and Leroux, L. A. 1996. Diets of Northern Pygmy-Owls and Northern Saw-whet Owls in west-central Montana. Wilson Bull. 108:123-128.

Holt, D. W., and Norton, W. D. 1986. Observations of nesting Northern Pygmy-Owls. J. Raptor Res. 20:39-41. 


\section{NOTES}

Kimball, H. H. 1925. Pygmy Owl killing a quail. Condor 27:209-210.

Lewin, V. 1963. Reproduction and development of young in a population of California Quail. Condor 65:249-278; doi 10.2307/1365353.

Merrill, J. C. 1888. Notes on the birds of Fort Klamath, Oregon. Auk 5:139-146; doi $10.2307 / 4067148$.

Sumner, E. L. Jr. 1935. A life history study of the California Quail, with recommendations for its conservation and management. Calif. Fish and Game 21:167-344.

Walker, A. 1924. Notes on some birds from Tillamook County, Oregon. Condor 26:180-182; doi 10.2307/1363172.

Accepted 11 December 2019

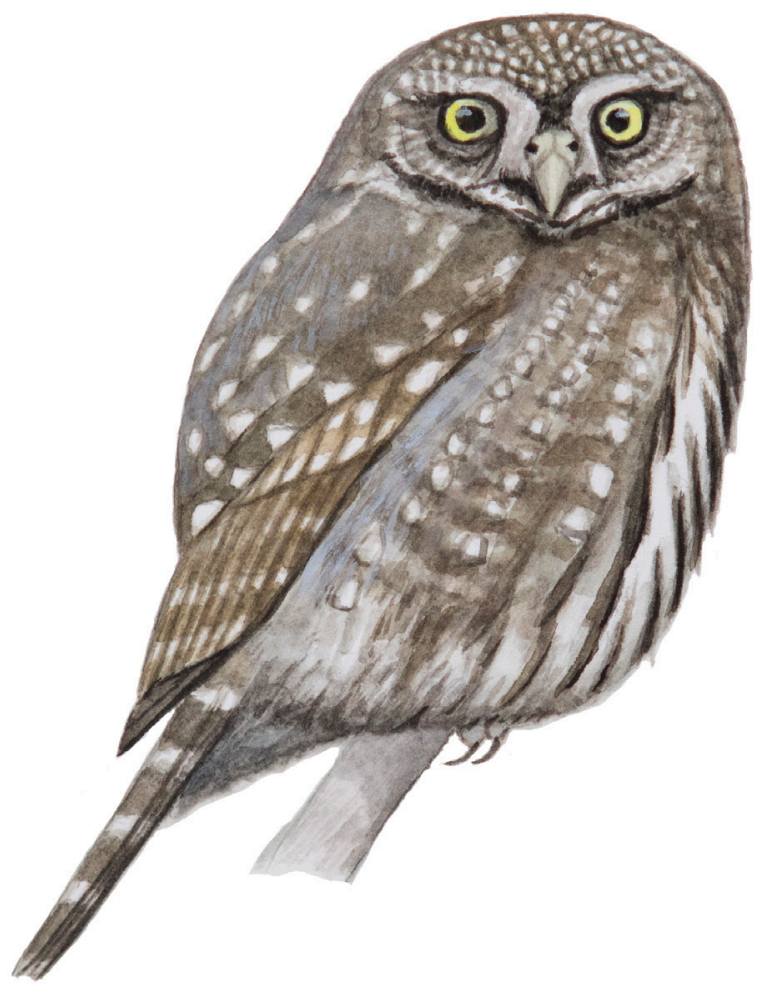

Northern Pygmy-Owl

Painting by Bryce Robinson 